\title{
Penggunaan antigen p24, IDR-Gp41 dan ID2-Pol dalam uji aviditas untuk identifikasi kasus baru pada infeksi HIV-1
}

\author{
Julian Eva Arifa ${ }^{1}$, Budiman Bela ${ }^{2,3 *}$, Silvia Tri Widyaningtyas ${ }^{2}$, Jeanne Elvia Christian ${ }^{2}$ \\ ${ }^{1}$ Magister Ilmu Biomedik, Fakultas Kedokteran, Universitas Indonesia \\ ${ }^{2}$ Pusat Riset Virologi dan Kanker Patobiologi Fakultas Kedokteran Universitas Indonesia- \\ ${ }^{3}$ Departemen Mikrobiologi, Fakultas Kedokteran, Universitas Indonesia \\ "E-mail : budiman.bela@ui.ac.id ; budiman.bela@yahoo.com
}

\begin{abstract}
AIDS is a severe immunodeficiency disease caused by HIV. Identification of new HIV infection in a population is required for the evaluation of intervention strategy of HIV-1 transmission. The avidity assay has been promoted for HIV-1 detection. Avidity assay is based on affinity strength of the epitopes of the HIV antigen against its specific corresponding antibodies. The binding of the antigen - the antibody formed in the initial phase of infection is relatively weak and easy to break with chaotropic reagents. In contrary, the antigenantibody binding formation in long-term infection is strong and not easily broken by addition of chaotropic reagents. Commercial avidity assays are available, however the antigens used might not be compatible with the circulating HIV strains in Indonesia. This research aimed to identify the most appropriate antigen candidate for avidity assay, three structural proteins from HIV were used i.e., p24, IDR-gp41 and ID2-Pol employed from the HIV strains circulating in Indonesia. The avidity assay was performed based on ELISA with pH 3 sodium citrate as chaotropic reagent. Serum samples was previously determined as positive and negative reactive by the Indonesian Red Cross. Each sample was tested in triplicates. The results of the avidity index were compared with the corresponding pattern of reactivity shown by Western Blotting. Comparative analysis of the avidity index using the IDR-Gp41 antigen showed correlation with increased value of avidity index with the completeness of the Western Blot reactivity pattern. This finding is not true in antigen ID2-Pol, and p24. Based on the results of the study, it can be concluded that IDR-Gp41 antigen has potential to be used in HIV avidity assay that is based on circulating strains of HIV in Indonesia.
\end{abstract}

Key words : avidity assay, HIV-1, IDR-Gp41, p24, ID2-Pol

\begin{abstract}
Abstrak
AIDS merupakan penyakit imunodefisiensi berat yang disebabkan oleh HIV. Penentuan infeksi baru HIV-1 pada level populasi diperlukan guna evaluasi strategi intervensi pencegahan penularan HIV-1. Uji aviditas telah diajukan sebagai salah satu uji deteksi HIV-1. Prinsip uji aviditas adalah kekuatan afinitas epitope antigen HIV terhadap antibodi spesifik yang mengenali epitop tersebut. Ikatan antigen-antibodi yang terbentuk pada fase awal infeksi merupakan ikatan yang lemah dan mudah diputuskan dengan pemberian reagensia chaotropic. Pada fase infeksi lama, ikatan antigen-antibodi yang terbentuk merupakan ikatan yang kuat sehingga tidak mudah diputuskan oleh pemberian reagensia chaotropic. Uji aviditas komersial telah tersedia namun antigen yang digunakan belum tentu sesuai dengan galur HIV yang beredar di Indonesia. Pada penelitian ini digunakan 3 kandidat antigen yaitu p24, IDR-gp41 dan ID2-Pol dari galur HIV yang beredar di Indonesia, untuk menentukan kandidat yang sesuai. Uji aviditas dilakukan dengan prinsip ELISA dengan sodium sitrat pH 3 sebagai reagensia chaotropic. Sampel yang diujikan adalah sampel serum yang telah ditentukan reaktivitasnya sebagai positif dan negatif oleh Palang Merah Indonesia. Sampel diuji secara triplikat. Hasil indeks aviditas sampel dibandingkan dengan pola reaktivitasnya pada uji Western Blot. Analisis perbandingan menunjukkan bahwa peningkatan nilai indeks aviditas yang menggunakan antigen IDR-Gp41 berkorelasi dengan kelengkapan pola reaktivitas uji Western Blot. Hal ini tidak ditemukan pada pengujian menggunakan antigen IDR-Pol2, dan p24. Berdasarkan hasil penelitian, dapat disimpulkan bahwa antigen IDR-Gp41 berpotensi untuk digunakan lebih lanjut dalam pengembangan uji aviditas HIV berbasis galur HIV yang beredar di Indonesia.
\end{abstract}

Kata kunci : Uji aviditas, HIV-1, IDR-Gp41, p24, ID2-Pol 


\section{Pendahuluan}

Human Immunodeficiency Virus-1 (HIV-1) merupakan virus penyebab penyakit infeksi kronik yang pada sebagian besar kasus akan berlanjut pada stadium AIDS. Menurut UNAIDS, pada tahun 2015 pengidap HIV/AIDS di seluruh dunia kurang lebih 36,7 juta (34 juta 39,8 juta) dengan jumlah infeksi baru sebanyak 2,1 juta (1,8 juta - 2,4 juta) dan jumlah kematian sebanyak 1,1 juta orang. ${ }^{1}$

Berdasarkan data Departemen Kesehatan tahun 2014, jumlah kasus HIV/AIDS di Indonesia meningkat dari tahun ke tahun sejak dilaporkan tahun 1987 dengan case fatality rate (CFR) yang menurun sejak 10 tahun terakhir. Pada tahun 2004, CFR HIV-1 adalah 13,86\% dan menurun menjadi $0,46 \%$ pada tahun 2014. ${ }^{1}$ Hal ini menunjukkan keberhasilan program pengendalian HIV/AIDS di Indonesia. Keberhasilan program pengendalian HIV selayaknya disertai dengan upaya monitoring kasus infeksi baru terutama dalam kelompok berisiko tinggi, sehingga intervensi awal pencegahan transmisi HIV pada populasi tersebut dapat dilakukan. ${ }^{2}$

Uji insidensi dan penentuan kasus baru infeksi HIV-1 biasanya dilakukan pada level populasi. Estimasi laju insiden pada level populasi merupakan salah satu elemen penting untuk mengukur dinamika dan perkembangan epidemi HIV sehingga dapat dilakukan usaha pencegahan yang adekuat dan untuk memonitor intervensi dan menduga efek yang mungkin timbul dari pengobatan terhadap HIV.

Uji insidensi umum dilakukan dengan pendekatan serologi menggunakan marka biologi spesifik virus dan fase serokonversi. Dari hasil uji dapat diketahui fase infeksi suatu individu sebagai infeksi baru (newly infected) atau infeksi lama (long-term infected) jika didapatkan hasil uji yang termasuk atau di luar standar yang ditetapkan. Menurut Morgado et al 2011 ${ }^{3}$, kategori infeksi awal HIV adalah infeksi yang berada dalam kurun waktu satu tahun setelah terpapar virus. Dalam tahap awal infeksi, tubuh memproduksi antibodi terhadap protein HIV terutama terhadap envelop (gp120 dan gp41), Gag (p24) dan polimerase $(\mathrm{p} 31)^{4}$. Oleh karena itu dalam pengembangan uji aviditas ini antigen struktural HIV, antara lain Gag (p24), Polimerase (ID2-Pol) dan Envelope (IDRGp41).

Uji aviditas telah diajukan sebagai salah satu pendekatan uji insidensi. Prinsip dasar uji aviditas adalah kekuatan ikatan antara antigen dan antibodi dan kadar titer antibodi. Antibodi yang diproduksi pada fase awal infeksi akan membentuk ikatan lemah dengan antigen sehingga aviditasnya rendah. Seiring lama berlangsungnya suatu infeksi kronik, ikatan antigen - antibodi akan menguat akibat stimulasi kronik dengan antigen pathogen, sehingga aviditasnya akan meningkat. ${ }^{5}$ Indeks aviditas diukur berdasarkan rasio antara nilai OD (optical density) sampel dengan chaotropic reagent OD sampel dengan PBS dan dinyatakan dalam persen. Infeksi baru, kurang dari 6 bulan, akan menunjukkan nilai aviditas yang rendah (kurang dari 50\%). Sementara infeksi jangka panjang, lebih dari 12 bulan, akan menunjukkan nilai aviditas tinggi (berkisar $80-100 \%)^{3}$

Kit komersial uji aviditas telah tersedia di pasaran. Namun dalam upaya penyediaan sistem uji aviditas yang dapat dimanfaatkan untuk menilai insidensi kasus HIV di Indonesia, maka dalam penelitian ini dilakukan upaya pengembangan sistem uji yang didasarkan pada sub tipe virus HIV-1 yang ada di Indonesia. Subtipe HIV-1 yang beredar di Indonesia didominasi oleh subtipe CRF01_AE， B， C, dan CRF02_AG. Protein yang digunakan dalam penelitian ini adalah IDR-Gp41, ID2-Pol yang diambil dari immunodominant region subtipe HIV-1 yang beredar di Indonesia. Immunodomminant region merupakan daerah yang dikenali oleh HIV-1 sehingga memicu pembentukan antibodi dalam jumlah berlimpah namun tidak 
menimbulkan efek netralisasi. ${ }^{6}$ Selain kedua protein tersebut, protein lain yang digunakan adalah p24 yang merupakan antigen Gag HIV-1.

\section{Metode}

Semua bahan yang digunakan dalam penelitian ini diperoleh dari laboratorium PRVKP FKUI-RSCM. Sampel berasal dari serum dari orang dengan HIV AIDS (ODHA) yang berasal dari pasien surveilance dan monitoring HIVDR P2PL yang diselenggarakan di PRVKP FKUIRSCM dan dari PMI. Dokumen kerahasiaan ODHA dan informed consent disimpan di P2PL. Pasien juga telah menandatangani informed consent untuk penelitian selain HIV-DR.

Sampel yang digunakan umumnya berasal dari HIV-1 subtipe CRF01_AE dan B dan telah seluruhnya dikarakterisasi menggunakan metode Western Blot. Total seluruh sampel yang digunakan adalah 78 sampel, yang terdiri atas 39 sampel positif HIV-AIDS dan 39 sampel negatif HIVAIDS.

Untuk mengetahui konsentrasi antigen dan antibodi yang efektif dilakukan optimasi. Menggunakan serum positif dan negatif yang diujikan pada berbagai konsentrasi antigen dan antibodi pada plat yang sama, optimasi dilakukan dengan menguji masing-masing antigen di dalam well terpisah pada konsentrasi 50 $\mu \mathrm{g} / \mathrm{ml}, 25 \mu \mathrm{g} / \mathrm{ml}$ dan $12,5 \mu \mathrm{g} / \mathrm{ml}$. Ke dalam masing - masing well antigen ditambahkan antibodi dengan konsentrasi berturut-turut 1/100, 1/50 dan 1/25. Cara kerja optimasi sama seperti uji ELISA.

Untuk uji ELISA, antigen diencerkan menggunakan buffer carbonatebicarbonate 1x pH 9,6 sampai konsentrasi yang diharapkan. Antigen terlarut dimasukkan dalam pelat ELISA dan diinkubasi semalam pada suhu $4{ }^{0} \mathrm{C}$. Kemudian dilakukan pencucian sebanyak 3 kali menggunakan $200 \mu 1$ washing buffer (PBS 1X-0,1\% TritonX). Selanjutnya ke dalam setiap sumur ELISA ditambahkan
$140 \mu \mathrm{l}$ blocking buffer (5\% susu skim dalam PBS-0,1\% Triton X) dan diinkubasi pada $37^{\circ} \mathrm{C}$ selama 1 jam. Setelah itu, dilakukan pencucian dengan washing buffer sebanyak 3 kali. Tahapan berikutnya adalah penambahan antibodi I berupa serum pasien yang telah diencerkan 1:100 dengan larutan 5\% susu skim dalam PBS-Triton X. Serum yang telah diencerkan dimasukkan ke dalam sumur ELISA sebanyak $50 \mu \mathrm{l}$ dan diinkubasi pada $37^{\circ} \mathrm{C}$ selama 1 jam. Selanjutya dilakukan pencucian sebanyak 5 kali. Tahapan selanjutnya adalah penambahan antibodi II berupa anti- $\alpha$ IgG manusia sebanyak $50 \mu \mathrm{l}$ yang dilarutkan dalam $5 \%$ susu skim dalam PBS-Triton $\mathrm{X}$ dengan perbandingan 1:10.000 dan diinkubasi pada $37^{\circ} \mathrm{C}$ selama 1 jam. Pelat kemudian dicuci sebanyak 5 kali. Sebanyak $50 \mu \mathrm{l}$ Streptavidine berlabel HRP yang dilarutkan dalam PBS dengan perbandingan 1:10.000 kemudian ditambahkan ke dalam pelat ELISA, dan diinkubasi pada $37^{\circ} \mathrm{C}$ selama 1 jam. Pelat kemudian dicuci sebanyak 5 kali. Sebanyak $50 \quad \mu 1 \quad$ O-Phenilenediamine dilarutkan dalam $10 \mathrm{ml}$ buffer substrat, kemudian pelat didiamkan pada suhu ruang hingga terbentuk warna. Ke dalam pelat ditambahkan $25 \mu \mathrm{l} 2,5 \quad \mathrm{M} \mathrm{H}_{2} \mathrm{SO}_{4}$ sebagai stop solution. Pembacaan OD pada ELISA reader dilakukan pada panjang gelombang $490 \mathrm{~nm}$.

Langkah pengerjaan uji aviditas sama dengan uji ELISA hanya terdapat sedikit perbedaan pada tahap inkubasi setelah pencucian antibodi pertama dilakukan penambahan $100 \mu \mathrm{l}$ pelarut sitrat $(0,1 \mathrm{M}$ asam sitrat monohidrat dan $0,1 \mathrm{M}$ trisodium sitrat monohidrat dengan perbandingan 1:4,5, $\mathrm{pH} 3$ ). Plat kemudian diinkubasi pada suhu $37^{\circ} \mathrm{C}$ selama 15 menit dan dilakukan lima kali pencucian. Tahapan pengerjaan selanjutnya sama seperti uji ELISA. Perhitungan nilai aviditas dilakukan mengikuti rumus berikut: 


$$
\mathrm{AI}=\frac{\mathrm{OD} \text { treatment }}{\text { OD tanpa treatment }} \times 100 \%
$$

Perhitungan data dilakukan dengan program Excel dan Prism 5.0.

\section{Hasil}

Nilai konsentrasi optimal antigen dan antibodi ditunjukkan oleh beda nyata antara kelompok sampel positif dan negatif yang diujikan. Dari hasil optimasi diketahui konsentrasi antigen optimal berturut-turut : IDR-p24 $=12,5 \mu \mathrm{g} / \mathrm{ml}$, IDR-gp41 $=50 \mu \mathrm{g} / \mathrm{ml}$ dan ID2-Pol $=12,5$ $\mu \mathrm{g} / \mathrm{ml}$ dengan konsentrasi antibodi $1 / 100$ untuk ketiga protein.
Sebanyak 39 sampel serum HIV positif dan 34 sampel serum negatif HIV menurut uji PMI, diujikan untuk mengetahui reaktivitas serum. Serum negatif digunakan untuk menentukan nilai ambang (cut off) dari masing-masing protein untuk uji ELISA. Serum dinyatakan reaktif terhadap suatu protein jika memiliki nilai OD di atas cut off, dan dinyatakan tidak reaktif jika nilai OD suatu serum berada di bawah cut off. Berdasarkan nilai cut off diketahui terdapat $69,23 \%$ (27/39) sampel reaktif terhadap antigen p24, 69,23\% (27/39) sampel reaktif terhdap antigen IDR-Gp41 dan $56,41 \%(22 / 39)$ reaktif terhadap antigen ID2-Pol (Grafik 1).

A
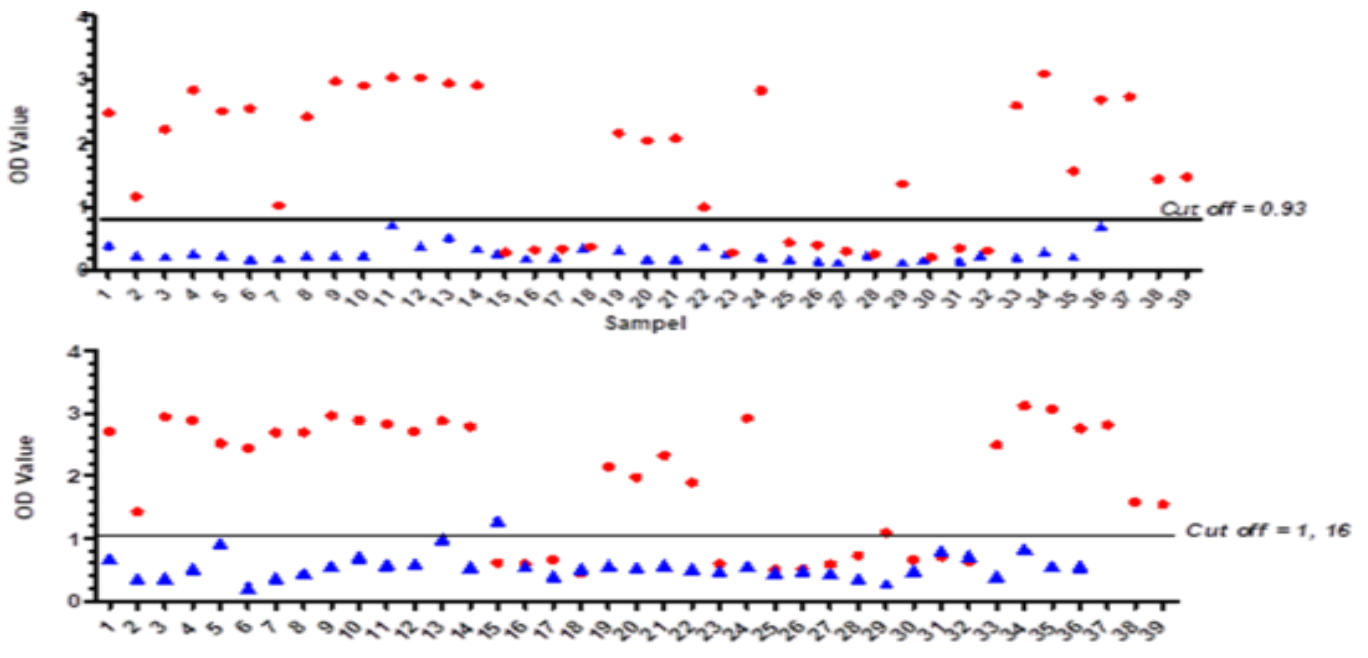

B

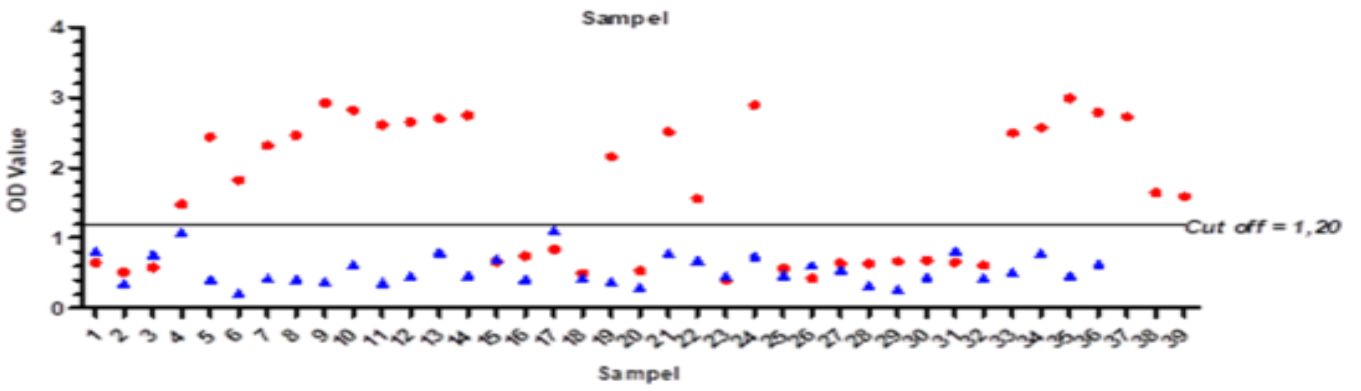

Gambar 1. Hasil uji reaktivitas sampel HIV positif dan HIV negatif berdasarkan uji MI terhadap antigen (A) p24, (B) IDR-Gp41 dan (C) ID2-Pol. Sampel positif disimbolkan oleh (๑) dan simbol sampel negatif adalah (C) . 
Sampel yang reaktif terhadap protein uji, kemudian diuji lebih lanjut untuk mengetahui indeks aviditas setiap sampel. Sebaran nilai aviditas sampel terhadap masing-masing antigen dapat dilihat pada Tabel 1 dan Grafik 2.

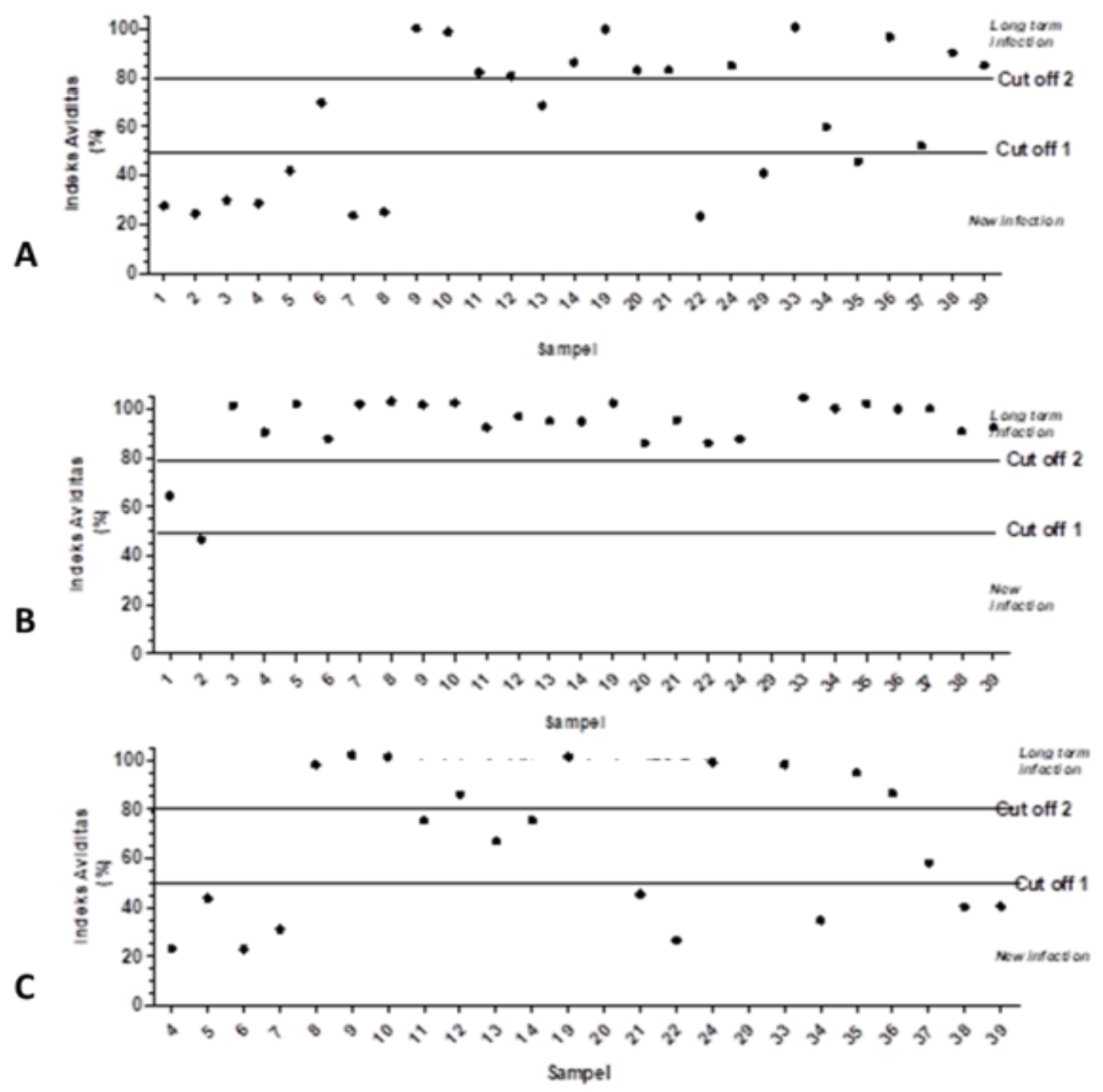

Gambar 2. Indeks aviditas sampel positif terhadap antigen (A) p24, (B) IDR-Gp41 dan (C) ID2-Pol. 
Tabel 1. Persentase sampel berdasarkan kriteria Indeks Aviditas (IA) terhadap antigen p24, IDR-Gp41 dan ID2-Pol

\begin{tabular}{lccc}
\hline Antigen (N) & \multicolumn{3}{c}{ Kategori infeksi sampel berdasarkan indeks aviditas } \\
\cline { 2 - 4 } & $\begin{array}{c}\text { IA }<50 \% \text { Infeksi } \\
\text { awal (<6 bulan) }\end{array}$ & $\begin{array}{c}\text { IA 50\%-80\% Infeksi } \\
\text { awal (6-12 bulan) }\end{array}$ & $\begin{array}{c}\text { 80-100\% (infeksi } \\
>12 \text { bulan) }\end{array}$ \\
\hline p24 (27) & $37,04 \%$ & $14,81 \%$ & $48,15 \%$ \\
IDR-Gp41 (27) & $3,7 \%$ & $3,7 \%$ & $92,59 \%$ \\
ID2-Pol (22) & $40,90 \%$ & $18,18 \%$ & $40,90 \%$ \\
\hline
\end{tabular}

$\mathrm{N}=$ jumlah sampel reaktif terhadap protein uji.

Nilai indeks aviditas kemudian dibandingkan dengan pola reaktivitas pita Western Blot. Hasil menunjukkan, nilai indeks aviditas terhadap p24 dan ID2-Pol tidak menunjukkan adanya korelasi dengan kelengkapan pita Western Blot. Hal yang berbeda ditemui pada antigen
IDR-Gp41 karena meningkatnya nilai indeks aviditas terhadap antigen IDRGp41 berkorelasi dengan kelengkapan pola pita reaktivitas Western Blot (Grafik $3)$.

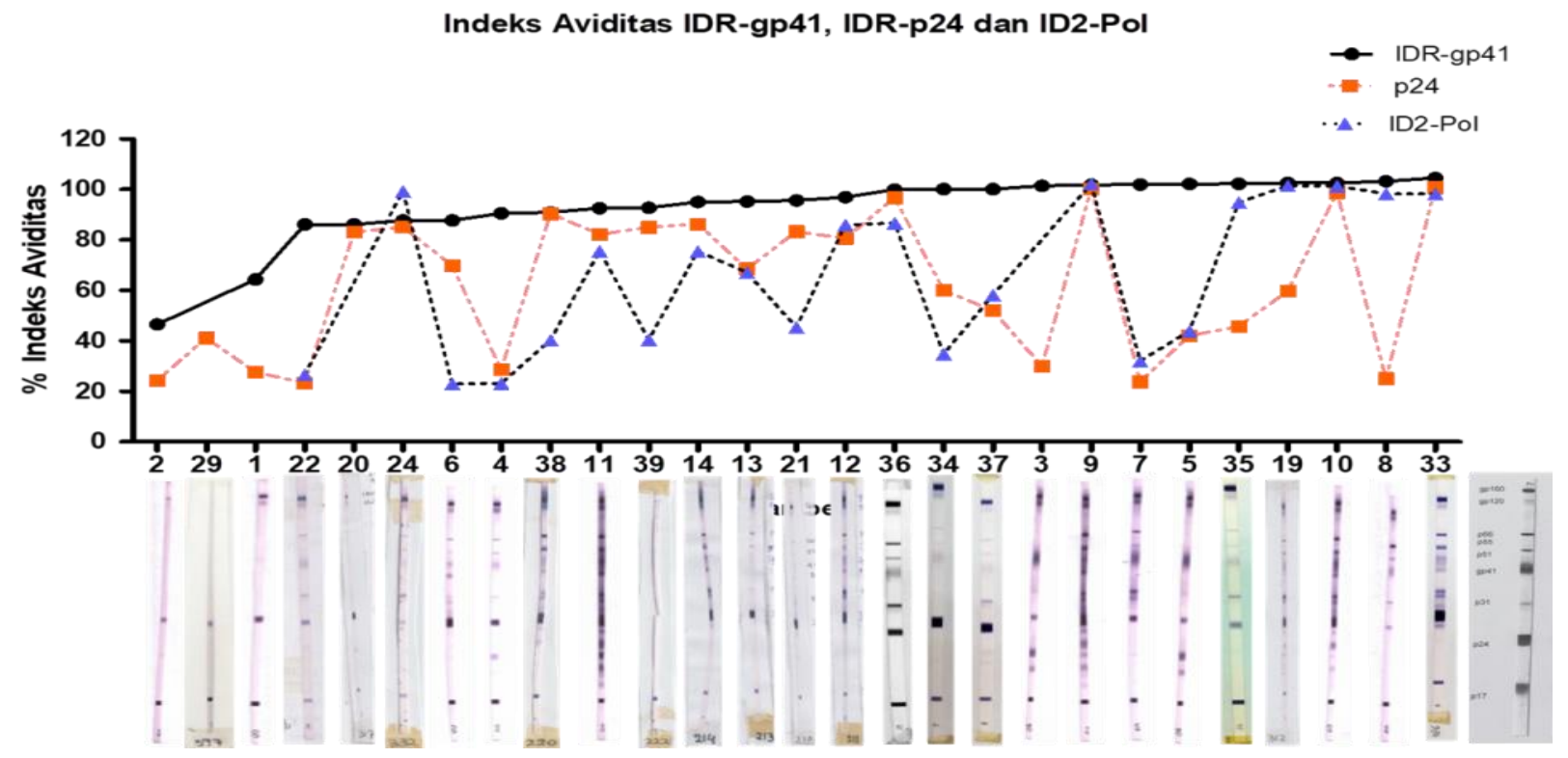

Gambar 3. Perbandingan nilai indeks aviditas dengan kelengkapan pola pita reaktivitas Western Blot. 


\section{Pembahasan}

Optimasi merupakan tahap yang diperlukan guna mengetahui konsentrasi optimal antigen dan antibodi yang digunakan, sehingga kompleks antigenantibodi yang dibentuk dapat dideteksi oleh konjugat dengan baik. ${ }^{7}$

$\mathrm{CoV}$ (Coefficient of Variation) diperlukan sebagai kontrol kualitas. Nilai $\mathrm{CoV}$ menunjukkan presisi uji ELISA yang dilakukan pada pelat berbeda. ${ }^{8}$ Nilai $\mathrm{CoV}$ yang diterima adalah di bawah $20 \%$. $^{9}$ Pada penelitian nilai $\mathrm{CoV}$ yang didapatkan adalah $17,3 \%$, sehingga merupakan nilai yang dapat diterima. Hal ini menunjukkan perbedaan hasil pada uji ELISA tidak dipengaruhi oleh kesalahan teknis akibat kesalahan manusia maupun kondisi reagen atau kondisi luar yang lain.

Dari keseluruhan sampel yang dinyatakan sebagai sampel HIV positif oleh PMI, terdapat 29 sampel reaktif terhadap protein uji. Sampel yang tidak reaktif diduga karena tidak memiliki antibodi spesifik terhadap antigen HIV-1 yang diujikan. Hal ini didukung dengan hasil Western Blot (WB) pada penelitian terpisah yang menunjukkan bahwa sampel-sampel negatif tidak menunjukkan pita reaktivitas. Hasil negatif juga ditunjukkan oleh sampel-sampel intermediate berdasarkan uji WB. Selain itu terdapat sampel dengan hasil positif uji WB namun tidak memberikan hasil positif uji ELISA dan ditemukan sampel yang tidak dapat mendeteksi adanya antigen p31 pada uji WB dan tidak memberikan hasil positif pada uji Elisa dengan antigen p31. Hal ini dapat disebabkan perbedaan subtipe HIV-1 yang digunakan sebagai sumber antigen uji dengan HIV-1 yang menginfeksi, sehingga tidak terdeteksi oleh uji ELISA. ${ }^{9}$

Sampel reaktif kemudian diuji lebih lanjut untuk diketahui indeks aviditas dari masing-masing sampel. Dari sebaran indeks aviditas diketahui bahwa antigen IDR-Gp41 menunjukkan korelasi dengan kelengkapan pola pita reaktivitas WB, namun tidak demikian untuk antigen p24 dan ID2-Pol. Hal ini mengindikasikan bahwa antigen IDR-Gp41 dapat digunakan untuk uji aviditas, sedangkan antigen Gag dan Pol tidak sensitif untuk uji ini. Hal ini sesuai dengan yang dilaporkan oleh Duong et al (2011). ${ }^{10}$ Pemanfaatan bagian Gp41 sebagai antigen dalam uji aviditas telah pula dilaporkan oleh Wei et al (2010). ${ }^{11}$

Antibodi terhadap Gp41 merupakan antibodi yang pertama kali muncul pada infeksi HIV, yaitu 13 hari setelah infeksi. Sementara itu, antibodi terhadap Gp120 muncul pada hari ke 40 setelah infeksi. ${ }^{4}$ Respon terhadap protein fungsional HIV (gag dan pol) muncul berturut-turut pada hari ke-18 (p24, p55), ke-33 (p17) dan hari ke 53 (p31). ${ }^{12}$

Penentuan awal infeksi sulit untuk dipastikan karena fase-fase awal infeksi HIV-1 tidak memberikan gejala yang khas. Penggunaan nilai indeks aviditas dapat diterapkan pada perkiraan periode infeksi yang terjadi pada suatu individu.

Perkiraan periode infeksi menggunakan indeks aviditas ditentukan didasarkan pada dua nilai ambang (cut off), yaitu $50 \%$ dan $80 \%$ sebagai penanda periode infeksi. Merujuk pada Morgado (2011), indeks aviditas kurang dari 50\% (low avidity) merupakan indikator infeksi baru dengan periode infeksi hingga 6 bulan, sedangkan indeks aviditas $\geq 80 \%$ (high avidity) merupakan indikator infeksi lama dengan perkiraan periode infeksi telah berlangsung lebih dari 12 bulan. ${ }^{1}$ Berdasarkan nilai indeks aviditas terhadap IRD-Gp41, maka ada 2 sampel yang memiliki nilai indeks aviditas kurang $80 \%$. Hal tersebut menunjukkan kedua sampel berasal dari orang yang terinfeksi HIV-1 kurang dari satu tahun.

Terdapat beberapa kriteria waktu infeksi baru. Jika penentuan kategori didasarkan pada Recent Infection Testing Algorithm (RITA), infeksi baru adalah infeksi yang sudah berlangsung antara 4- 
12 bulan. $^{13}$ Kriteria lain diajukan oleh Consortium for the evaluation and performance of HIV incidence (CEPHIA) yang menetapkan periode infeksi dibawah 2 tahun sebagai infeksi baru. ${ }^{14}$

\section{Kesimpulan}

Konsentrasi antigen p24, IDR-Gp41 dan ID2-Pol untuk uji Elisa dan uji aviditas berturut-turut adalah $2,5 \mu \mathrm{g} / \mathrm{ml}$, $50 \mu \mathrm{g} / \mathrm{ml}$ dan $12,5 \mu \mathrm{g} / \mathrm{ml}$ dengan pengenceran serum optimal untuk ELISA dan uji aviditas adalah 1/100.

Antigen IDR-Gp41 dapat dimanfaatkan untuk uji aviditas sedangkan antigen p24 dan ID2-Pol tidak dapat dimanfaatkan untuk uji aviditas.

\section{Saran}

Dilakukan evaluasi untuk meningkatkan sensitivitas dan spesifisitas uji aviditas berdasarkan antigen IDRGp41, sehingga dapat dimanfaatkan dalam program pengendalian HIV di Indonesia.

\section{Ucapan Terima Kasih}

Terima kasih kepada Pusat Riset Virus dan Kanker Patobiologi (PRVKP) FKUIRSCM dan SINAS HIV atas terselenggaranya penelitian ini.

\section{Daftar Rujukan}

1. Ditjen PP dan PL Kemenkes RI. Statistik kasus HIV/AIDS di Indonesia berdasarkan jenis kelamin/sex dilapor sampai dengan September 2014. Diunduh dari: www.depkes.go.id/resources/download/pusdati n/infodatin\%20AIDS.pdf tanggal 16 Agustus 2016.

2. Family Health International. Assays to estimate HIV incidence and detect acute HIV infection. Global Landscape and Market Assessment, Annual Report, 2009.

3. Morgado, M.G, Bastos, F.I. Estimates of HIV1 incidence based on serological method: a brief methodological methods. Cod Saude Publica 2011; 27Sup 1: 517 - 518.

4. Tomaras G.D, Haynes B.F, HIV-1 spesific antibody responses during acute and chronic
HIV-1 infection. Current Opinion in HIV/AIDS September 2009; 4(9): 373-9.

5. Khanna V, Bairy I, Marinda R, Comparison between avidity test and detuned ELISA test in detecting the recent and established HIV-1 infection. International Journal of Pharma and Bio Sciences 2012; 4: 865 - 890 .

6. Gallearno D., Cabautan C.R., Sibanda E.N., Valenta R., HIV specific antibody responses in infected patients: from a monoclonal view to polyclonal view. International Archives of Allergy and Immunology 2015 (167); 223-41.

7. Deshpande S.S, Enzyme immunoassays: from concept to development. Chapman and Hall, International Thomson Publishing. New York. 1996;314-8.

8. Reed G.F, Lynn F, Maude B.D, Use of coefficient of variability in assesing variability of quantitative assays. Clinical And Diagnostic Laboratory Immunology, Nov. 2002, 12351239.

9. Shetty S., Prabhu S., Hallikeri K., Krishnapilai R. Laboratory test for HIV: diagnosing, monitoring and managing AIDS - an overview. International Journal of Oral and Maxillofacial Pathology 2011; 2(11) 20-28.

10. Duong Y.T, Qiu M, De A.K., Jackson K, Dobbs T, Kim A.A., Nkengasong J.N., Parekh B.S., Detection of recent HIV-1 infection using a new limiting-antigen avidity assay: potential for HIV-1 incidence estimates and avidity maturation studies. PLoS ONE 2012; 7(3): e33328.

11. Wei X., Liu X., Dobbs T., Kuehl D., Nkengasong J.N., Hu D.K., Parekh B.S., Development of two avidity assays to detect recent HIV type 1 seroconversion using a multisubtype gp41 recombinant protein. AIDS Research and Human Retroviruses. 2010.16 (1): 61-71.

12. McMichael M.J., Borrow P., Tomaras G.D., Goonetilleke N., Haynes B.F. The immune response during HIV-1 infection: clues for vaccination development. National Review Immunology, January 2010; 10(1): 11-23.

13. WHO/UNAIDS. When and how to use assays for recent infection to estimate HIV incidence at a population level. WHO Library Cataloguing-in-Publication Data. 2011. ISBN 978924150138 (NLM classification: WX 147).

14. Cephia project team. Evaluation of Bio-Rad GS HIV-1/HIV-2 Plus O EIA Avidity Test: HIV antibody measurements for distinguishing recent HIV-1 infection using modified BioRad Genetic System HIV-1/HIV-2 Plus O EIA. Evaluation report Ver VI. 2015 